\title{
Potentially Toxic Element Content in Arid Agricultural Soils in South Iran
}

\author{
Tahereh Moghtaderi ${ }^{1}$, Ata Shakeri ${ }^{2}$ and Andrés Rodríguez-Seijo ${ }^{3,4, *(1)}$ \\ 1 Landscape and Green Spaces Organization of Shiraz Municipality Shiraz, Shiraz 71366-18947, Iran; \\ tmoghtaderi62@yahoo.com \\ 2 Department of Applied Geology, Faculty of Earth Science, Kharazmi University, 49 Mofatteh Avenue, \\ P.O.Box 15614, Tehran, Iran; atashakeri@khu.ac.ir \\ 3 Interdisciplinary Centre of Marine and Environmental Research (CIIMAR), University of Porto, Terminal de \\ Cruzeiros do Porto de Leixões, Av. General Norton de Matos s/n, 4450-208 Matosinhos, Portugal \\ 4 Department of Biology, Faculty of Sciences, University of Porto, Rua do Campo Alegre, \\ 4169-007 Porto, Portugal \\ * Correspondence: andres.seijo@fc.up.pt
}

Received: 16 March 2020; Accepted: 10 April 2020; Published: 14 April 2020

\begin{abstract}
Potentially toxic elements (PTE) are considered to be dangerous threats, both for human health and the environment. Here, the contamination level, sources, and ecological risks posed by PTE were investigated in 19 topsoils from agricultural lands in the Bandar Abbas County on the southern coast of Iran. The soil fraction $<63 \mu \mathrm{m}$ was used for the analysis of the pseudototal contents of PTE (arsenic, cadmium, cobalt, chromium, copper, lead, manganese, molybdenum, nickel, vanadium, and zinc). The results were analyzed using principal component analysis (PCA) and Pearson's correlations, different pollution indices [enrichment factor (EF), contamination factor (Cf), and modified degree of contamination (mCd), and the potential ecological risk index (PERI). The results of the pollution indices showed that the contamination levels of the studied agricultural soils are low to moderate, while the average PERI values indicate that the ecological risks of PTE range from low to high in the soils of the studied area. Correlations and PCA analyses suggest that studied elements have three possible origins: geogenic (chromium, cobalt, copper, manganese, vanadium, and zinc), anthropogenic (cadmium, nickel, phosphorus and lead) and atmospheric (arsenic) sources. These findings are helpful for the long-term assessment of PTE in the Bandar Abbas County.
\end{abstract}

Keywords: arid environment; metals; principal component analysis; soil contamination

\section{Introduction}

Soil plays an essential role in human development as an environment that supports life, a natural buffer of contaminants, a substrate for food production, and a source of biodiversity. However, soils are also highly impacted by anthropogenic activities as a result of industrialization and human development and are sometimes neglected in the environmental guidelines of national governments [1-6]. Agricultural soils, in particular, are essential for humans due to their role in food production, but are sometimes highly degraded at the physical, chemical, and biological levels by inorganic (potentially toxic elements, PTE) and organic contaminants [5,6]. These contaminants reach the soils due to agricultural activities (fertilization, pesticides, etc.) and/or the agricultural area's proximity to sources of soil contamination, such as industrial or urbanized areas, energy production infrastructure or landfills. Moreover, agricultural soil contamination is not only an environmental issue, since the potential transfer of contaminants from soils to crops can also pose a safety concern based on their risk to humans $[7,8]$. 
Iran has experienced widespread development in the last four decades, including fast urbanization of large areas, industrialization, and intensive agriculture in several regions. These changes have sometimes been accompanied by overlooked environmental depreciation [9-13]. In this sense, Bandar Abbas is one of Iran's most industrialized regions, hosting a major shipping hub, zinc-smelting industry, and an important petrochemical industry, including several petroleum industries and oil fields [9]. At the same time, it is an important agricultural area with the cultivation of crops such as wheat, barley, and sugar beet.

Soils in agricultural areas can be polluted by contaminants from industrial as well as urban developments, creating a risk for humans through the consumption of food cultivated in these soils, as indicated by Doabi et al. [12,13] for other regions of Iran. Although some works have highlighted the influences of anthropogenic activities on street dust [14] and industrial soils [9] on the study region, available information about the contamination levels and potential sources of PTE in the agricultural soils is still scarce.

This work is the first detailed research about the PTE accumulation in the farmlands of the Bandar Abbas region, an important region in Iran with more than 0.6 million inhabitants. The objectives of this study were: (1) to determine the main physicochemical soil properties (soil texture, $\mathrm{pH}$, organic carbon, and cation exchange capacity), and the levels of several PTE [arsenic (As), cadmium (Cd), cobalt (Co), chromium $(\mathrm{Cr})$, copper $(\mathrm{Cu})$, manganese $(\mathrm{Mn})$, molybdenum $(\mathrm{Mo})$, nickel $(\mathrm{Ni})$, lead $(\mathrm{Pb})$, vanadium $(\mathrm{V})$, and zinc ( $\mathrm{Zn})]$ in the agricultural soils from the study area; (2) to estimate the degree of contamination through several environmental indicators (contamination factor, enrichment factor, potential ecological risk index, and the modified degree of contamination), and (3) to identify the possible origin (natural or anthropogenic) of the studied elements.

\section{Materials and Methods}

\subsection{Study Area}

This study was performed in Bandar Abbas County South District (BAC); which covers $4063 \mathrm{~km}^{2}$ and is located at $27^{\circ} 00^{\prime}-27^{\circ} 30^{\prime} \mathrm{N}, 55^{\circ} 54^{\prime}-56^{\circ} 29^{\prime} \mathrm{E}$ [9]. The city of Bandar Abbas is the capital of the Hormozgan province and is the seventh most populated city in Iran. Figure 1 provides the location map and the selected samples in the study area. The climate of the study area is semi-arid to arid with an average precipitation of $250 \mathrm{~mm}$ and an annual temperature of $27.2^{\circ} \mathrm{C}$ [9,15]. It is recognized as one of the agricultural and industrial pole in Iran, with significant economical activities, such as fishing and commercial ports, petrochemical and steel, zinc and aluminum complexes, cement factories, etc. [10,16]. The major fertilizers used in this area are superphosphate, ammonium phosphate, and potassium chlorate fertilizers. The geology of the study area is mainly composed by limestone, shale, marl, sandstone, and conglomerate, while the soils are mainly entisoils and arid soils [9].

\subsection{Soil Collection and Sample Characterisation}

A total of 19 topsoil samples (0-10 cm sampling depth) were gathered from agricultural lands from BAC. Sampling sites were selected in such a way as to cover an impacted area based on recognized pollution sources such as industrial complex zones, landfills, etc. following the methodology developed for previous work with industrial areas [9]. Details about sampling methodology were previously indicated for industrial areas [9].

After the collection and once in the laboratory, samples were air-dried, sieved ( $2 \mathrm{~mm}$ nylon sieve) to eliminate impurities (e.g., stones, agricultural plastics, roots, or cigarette butts) following the methodology indicated by Keshavarzi et al. [14], ground with an agate mortar and pestle, and finally passed through a $63-\mu \mathrm{m}$ nylon sieve. The soil fraction $<63 \mu \mathrm{m}$ was selected for further metal analysis [17]. According to Zheng et al. [18] and Doabi et al. [12], the health risks associated with fine particles are more significant than those for coarser fractions. The physical and chemical properties of the studied samples were measured using standard methods for the $<2 \mathrm{~mm}$ fraction: soil $\mathrm{pH}(1: 5$, 
soil:water ratio), particle size distribution determined by Pippete method [19], organic carbon content was measured by titration method [20], and the cation exchange capacity (CEC) [21].

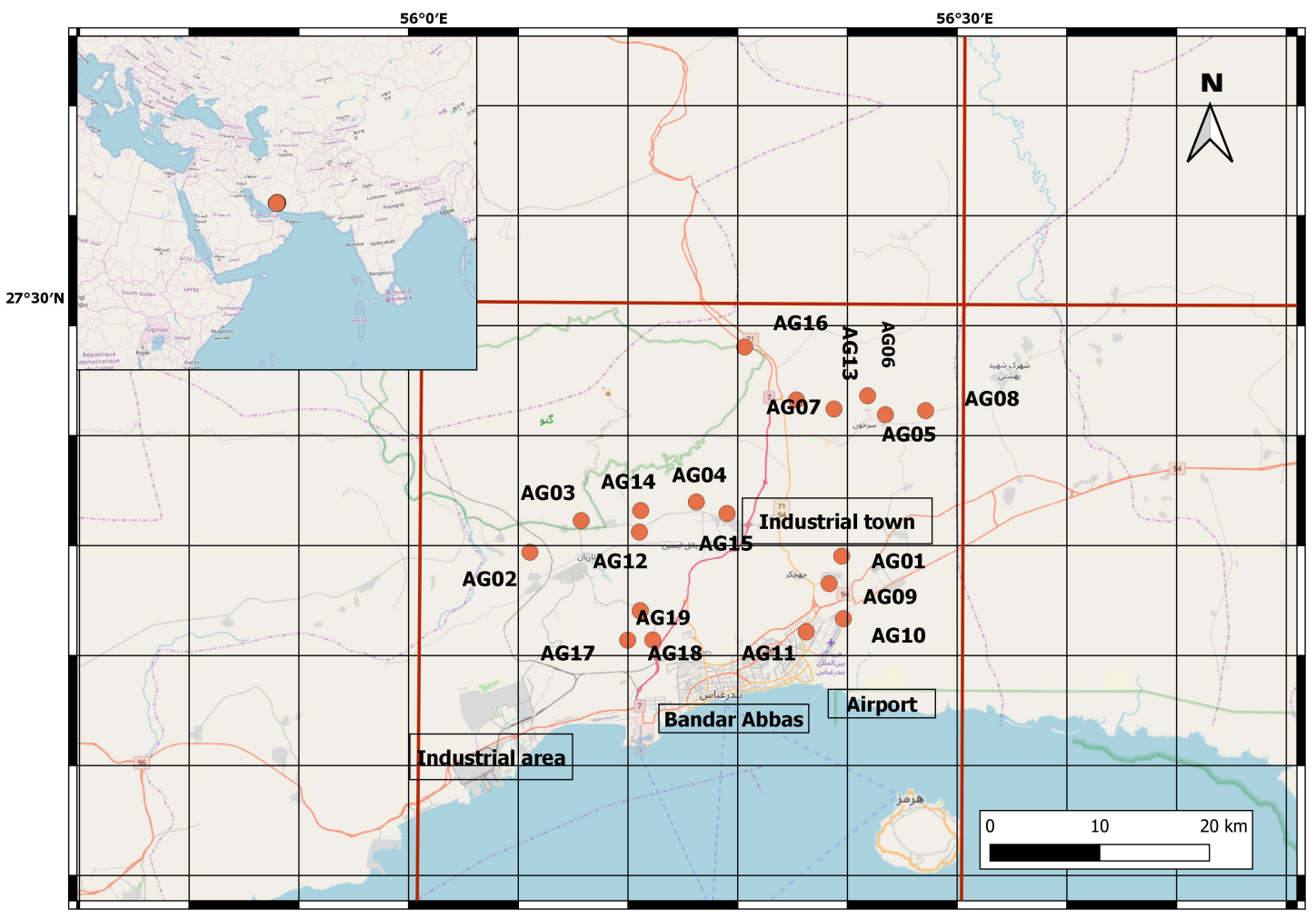

Figure 1. Study area and location of the sampling stations (orange dots).

The contents of the studied PTE [aluminum (Al), As, Cd, Co, Cr, Cr, iron (Fe), Mn, Mo, Ni, phosphorous $(\mathrm{P}), \mathrm{Pb}$, scandium $(\mathrm{Sc}), \mathrm{V}$, and $\mathrm{Zn}$ ] were measured using a mixture of different acid combinations $\left(\mathrm{HF}, \mathrm{HClO}_{4}, \mathrm{HNO}_{3}\right.$, and $\mathrm{H}_{2} \mathrm{O}_{2}$ ) following the methodology indicated in Moghtaderi et al. [9]. The concentrations of the selected elements were evaluated using ICP-MS (Agilent, 7700x, Santa Clara, CA, USA). Details about internal quality standards were previously indicated [9].

\subsection{Determination of Pollution Indices}

In accordance with several previous studies [17,22-24], different environmental indices were used to assess soil contamination on the basis of PTE concentrations, including the contamination factor (Cf), enrichment factor (EF), the modified degree of contamination $(\mathrm{mCd})$, and the potential ecological risk index (PERI). These indexes are widely used in different soils since can be used to assess the presence/intensity of a contaminant deposition on sediments or surface soils, allowing a quick and robust assessment of soil contamination e.g., [8,9,13,17,22-24]. As indicated by [25], these calculation methods allow converting numerical results into broad descriptive bands of pollution ranging from low to high intensity.

Cf was employed to evaluate the potential contamination of studied soils by individual elements [26]. It was calculated according to Hakanson (1980) using the following Equation (Equation (1)):

$$
\mathrm{Cf}=\mathrm{Mx} / \mathrm{Mb}
$$

where $\mathrm{Mx}$ and $\mathrm{Mb}$ are the contents of each PTE in the soil and reference environment, respectively is divided into four categories (Table S1). 
Abrahim [27] presents a modified and comprehensive version of Hakanson's [26] equation for the computation of the modified degree of contamination (mCd), following Shakeri et al. [28] and Krzysztof et al. [22] (Equation (2)):

$$
\mathrm{mCd}=\sum \mathrm{Cf} / \mathrm{n}
$$

where $\mathrm{n}$ is the number of 11 PTE. The different degrees of $\mathrm{mCd}$ are shown in Table S1.

PERI was used to determine the toxicity of PTE in the soils [26,29]). In accordance with this methodology, the potential ecological risk factor (Eir) of each PTE and the PERI of multiple elements can be calculated by Equation (3):

$$
\text { PERI }=\sum{ }^{n_{i=1}} E_{r}^{i}=\sum^{n_{i=1}} C f \times T_{r}^{i}
$$

where $\mathrm{Cf}$ and $\mathrm{Tr}$ are the contamination factor and toxic-response factor, respectively, for each PTE (i.e., each element of i). The toxic-response factors for $\mathrm{As}, \mathrm{Cd}, \mathrm{Cr}, \mathrm{Cu}, \mathrm{Ni}, \mathrm{Pb}$ and $\mathrm{Zn}$ are 10, 2, 5, 5, 30, 5, and 1. PERI indicates the sensitivity at the biological level to the PTE and explains the potential ecological risk caused by the overall contamination [30,31]. The degree of ecological risk of each element $\left(E_{r}^{i}\right)$ and the Potential Ecological risk Index (PERI) classes are shown in Table S1 [30-33].

The enrichment factor $(\mathrm{EF})$ relative to background was computed to measure the fractions of PTE in soil that originated from human sources/anthropogenic vs. lithogenic. It is supposed that the contents of $\mathrm{Al}, \mathrm{Fe}, \mathrm{Sc}$, and $\mathrm{Ti}$ in the soil can be described solely by geogenic source [23,34-36]. In this study, the EF was measured by the following Equation (Equation (4)):

$$
\mathrm{EF}=[\mathrm{M}] /[\mathrm{Sc}]_{\text {soil }} /[\mathrm{M}] /[\mathrm{Sc}]_{\text {background }}
$$

where $\mathrm{M}$ is the element under consideration and $\mathrm{Sc}$ is a reference element. The range of EF from 0.5 to 2 regarded as natural variation, while ratios higher than 2 represent enrichment due primarily to human inputs [31,37]. Finally, the EF values for each toxic element are classified in five categories that are shown in Table S1.

\subsection{Data Analysis}

Pearson's correlation analysis was carried out using R (v. 3.1.3, R Core Team, Vienna, Austria) to determine the associations between the different PTE. A Principal component analysis (PCA) was also carried out using SPSS 19.0 (Armonk, NY: IBM Corp.) to explore potential sources of toxic elements in agricultural soil samples from the study area. The PCA is an efficient statistical technique used to identify probable sources of PTE [38]. Varimax rotation with Kaiser Normalization was used to simplify the data and their interpretation $[10,11]$.

\section{Results and Discussion}

\subsection{Soil Physicochemical Properties and PTE Levels in Studied Soils}

Physicochemical properties of studied soils are shown in Table 1. Briefly, soils are loam and silt loam according to the USDA classification, with slightly to moderately alkaline soils. Organic matter content was lower (up to $1.13 \%$ ), while CEC values were lower. The values are similar to the samples from industrial soils previously characterized [9], although, in the agricultural soils, more alkaline values were observed but with less organic carbon content.

Regarding the studied PTE, only $\mathrm{Cr}$ and Ni showed higher levels that exceeded the Iranian Environmental Quality Standards for agricultural lands (200 and $110 \mathrm{mg} \cdot \mathrm{kg}^{-1}$, respectively) [13], and also the Canadian soil quality guidelines (CSQG) for agricultural soils (64 and $45 \mathrm{mg} \cdot \mathrm{kg}^{-1}$, respectively) [39]. Although these elevated levels can be related to the geogenic origin, according to the higher background levels of these elements $\left(74.5\right.$ and $77 \mathrm{mg} \cdot \mathrm{kg}^{-1}$, respectively), it's also widely known that $\mathrm{Cr}$ and $\mathrm{Ni}$ can be related to fertilizers, limestone and manures [40-43]. It was interesting 
also to advise that our soils have higher levels of $\mathrm{P}$, probably by the widespread use of sulfate and phosphate fertilizers as indicated by Keshavarzi al. for Iranian soils [44] that can reinforce the origin of $\mathrm{Cr}$ and $\mathrm{Ni}$ in our soils.

The PTE levels obtained in this studied were compared with data reported by other studies carried out for agricultural soils in Iran (Table 2). When compared with the results of previous studies in Iran e.g., [13,40,41,43-47], average values are similar or lower to indicate by them, probably due to some of these studies were carried out near to industrial areas e.g., [40,41]. Results showed significant enrichment of $\mathrm{Cr}$ and $\mathrm{Ni}$ in studied agricultural lands, although with similar values as indicated by Doabi et al. [13] for agricultural areas in Kermanshah province, Western Iran. When compared with other agricultural areas from arid/semiarid environments e.g., [3,48-52], our studied soils showed similar values to studies from other regions. In general, the contamination level of our samples was low, and higher contents seem to be related to inputs of fertilizers and pesticides [42,53], with a low influence from industrial or urban sources. 
Table 1. Summary statistics of physical and chemical properties and potentially toxic elements (PTE) levels (mg.kg ${ }^{-1}$ ) for the agricultural soil samples of Bandar Abbas County South District (BAC).

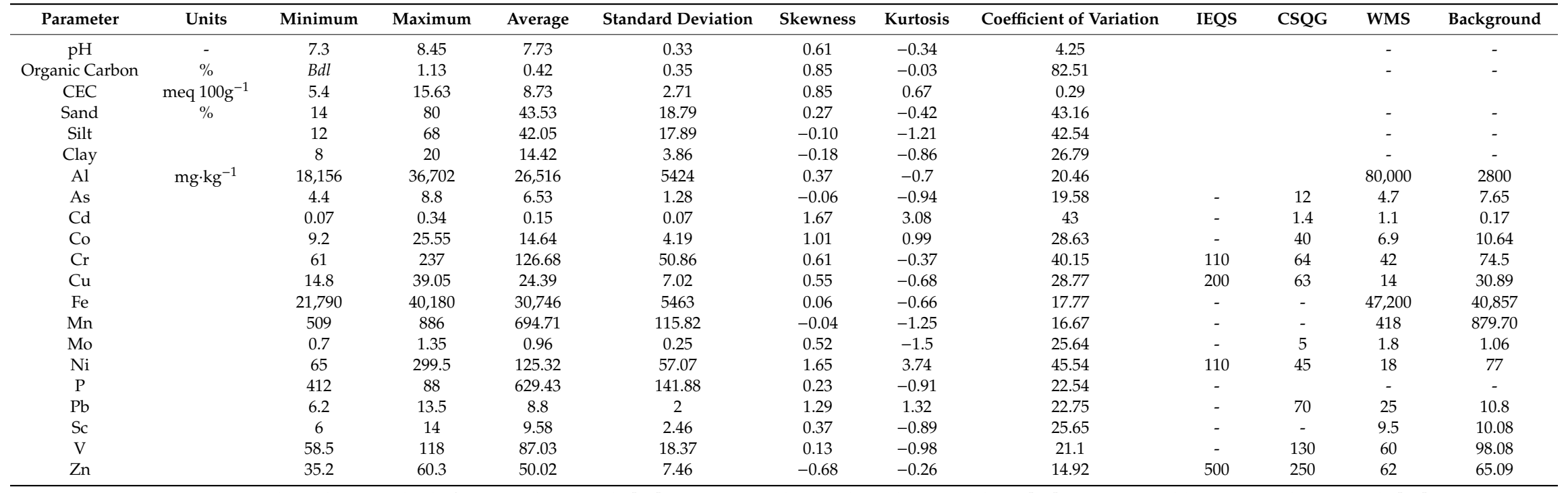

IEQS-Iranian Environmental Quality Standards for agricultural soils [13], CSQG Canadian Soil Quality Guidelines [39], WMS—World average values in soils [42], CEC Cation exchange capacity. 
Table 2. Comparison of studied PTE in agricultural soils between the present work and other studies from arid and semiarid environments (mean values, mg $\cdot \mathrm{kg}^{-1}$ ).

\begin{tabular}{|c|c|c|c|c|c|c|c|c|c|c|c|c|c|c|c|c|c|c|}
\hline Location & Soil Type & $n$ & Al & As & Cd & Co & $\mathrm{Cr}$ & $\mathrm{Cu}$ & $\mathrm{Fe}$ & Mn & Mo & $\mathrm{Ni}$ & $\mathbf{P}$ & $\mathbf{P b}$ & $\mathrm{Sb}$ & $\mathrm{V}$ & $\mathrm{Zn}$ & Reference \\
\hline Bandar Abbas, Southern Iran & AGS & 19 & 26,516 & 6.53 & 0.15 & 14.64 & 126.68 & 24.39 & 30,746 & 694.71 & 0.96 & 125.32 & 629.43 & 8.8 & - & 87.03 & 50.02 & This study \\
\hline Granada and Almeria provinces, South-East of Spain & AGS & 142 & - & - & 0.4 & - & 29.6 & 25.7 & - & - & - & 26.9 & 13.6 & 25.6 & - & - & 65.7 & [3] \\
\hline Kermanshah province, Western Iran & AGS & 53 & - & - & - & - & 79.21 & 41.21 & 25,936 & 559.06 & - & 131.46 & - & & & - & 74.62 & [13] \\
\hline Hamedan Province, Western Iran & AGS & 58 & - & - & - & - & - & - & 37,690 & 403.37 & & - & 21.98 & 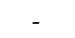 & 2.43 & - & - & [43] \\
\hline Teheran area, Northwestern Iran & AGS & 141 & - & - & - & - & 87.15 & - & - & 665.06 & - & 43.60 & - & 35.08 & - & 67.14 & 130.36 & [41] \\
\hline Industrial area Isfahan, Center Iran & AGS & 105 & 53,000 & - & 0.43 & 14.7 & 85.9 & 35.7 & 28,000 & 649.9 & - & 66.2 & - & 34.6 & - & - & 111.5 & [40] \\
\hline Isfahan Province, Center Iran & AGS & 114 & - & - & - & - & - & 35.28 & 35,600 & - & - & - & 3750 & 32.14 & - & - & 100.96 & [44] \\
\hline Qazvin Province, North-West Iran & AGS & 71 & - & - & 0.14 & 18.9 & 34.5 & 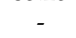 & - & - & - & - & - & 17.36 & - & - & - & [45] \\
\hline Semnan Province, Northern Iran & AGS & 47 & - & - & 0.3 & - & 83.7 & 24.3 & - & - & - & 33.3 & - & 18.1 & - & - & 80.4 & [46] \\
\hline Aghili plain, Khuzestan province, Western Iran & AGS & 55 & - & 2.81 & 0.29 & - & - & - & - & - & - & - & - & 6.12 & - & - & - & [47] \\
\hline Gansu Province, China & AGS & 5 & - & 8.8 & - & - & 40.1 & 17.1 & - & - & - & - & - & 23.30 & - & - & - & [48] \\
\hline Gansu Province, China & AGS-i & 13 & - & 11.17 & - & - & 38.82 & 27.2 & - & - & - & - & - & 21.44 & - & - & - & [48] \\
\hline Saiss plain, Northern Morocco & AGS-i & & - & & - & - & 78 & 55 & 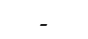 & - & - & 31 & - & & - & - & 119 & [49] \\
\hline Copiapó, Northern & AGS & 7 & - & 32.1 & - & 13.3 & - & 209 & 21,180 & 1049 & - & - & - & 50.4 & - & - & 176 & [50] \\
\hline Hebei Province, Eastern China & AGS & 100 & - & 6.16 & 0.15 & - & 57.77 & 21.22 & - & - & - & 25.04 & - & 18.80 & - & - & 69.96 & [51] \\
\hline Alicante province, Eastern Spain & AGS & 29 & - & - & 0.38 & 7.9 & 28.3 & 21.6 & 15,274 & 320 & - & 23.7 & - & 19.6 & - & - & 57.8 & [52] \\
\hline Castellón province, Eastern Spain & AGS & 77 & - & - & 0.32 & 7.7 & 33.3 & 36.6 & 16,915 & 385 & & 19.5 & & 55.8 & & & 78.5 & [53] \\
\hline
\end{tabular}

n—number of samples, AGS—Agricultural Soil, AGS-I—Agricultural irrigation soil. 


\subsection{Assessment of Potentially Toxic Elements Pollution}

The EF, Cf, $\mathrm{mCd}$, and PERI indexes were used to determine the possibility of PTE pollution in the studied soils. The ranges of average $\mathrm{EF}$ values for the agricultural areas for $\mathrm{Ni}, \mathrm{Cr}$, and $\mathrm{Cd}$ show that the soils are moderately enriched by these elements (Figure 2). In contrast, the average EF values for the other elements show that the agricultural soil samples were minimally enriched. PTE with low EF values $(<2)$ in the agricultural soil samples indicate that those elements originated from geogenic causes. Geological and lithological maps support this since, in the northeast (NE) of the study area, tuffs and shale were observed [9]. Higher concentrations of PTE have also been observed for similar environments like our study [31], where $\mathrm{Cr}$ and $\mathrm{Cd}$ showed moderate to severe enrichment.

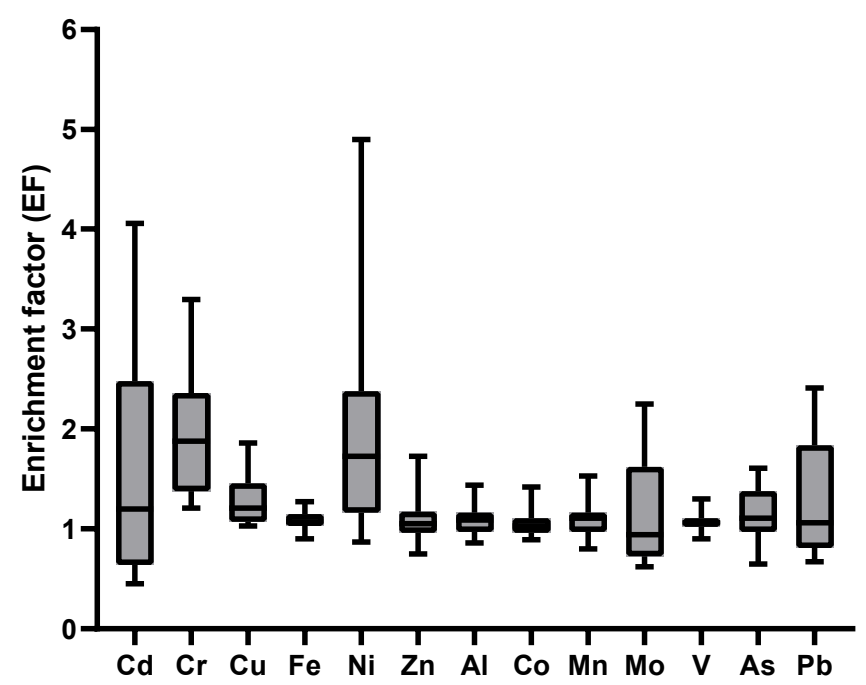

Figure 2. Box plot of the enrichment factor for studied PTE in agricultural soils.

Contamination factor (Cf) was determined based on the background concentrations of PTE in BAC soils (Figure 3). The highest $\mathrm{Cf}$ values were observed in agricultural soil samples collected from (AG5), (AG8), and (AG16). The mCd values in agricultural soil samples varied from 0.83 to 1.63 , with an average of 1.22, illustrating that the degree of contamination of these soil samples is very low.

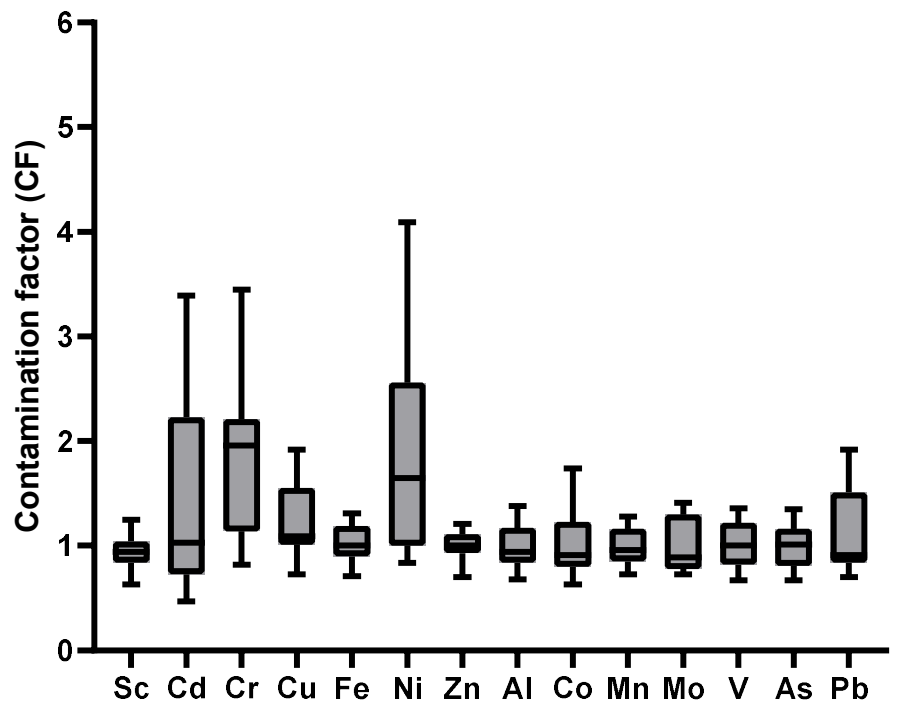

Figure 3. Box plot of the contamination factor for studied PTE in agricultural soils. 
PERI indicates the sensitivity of diverse functional groups to toxic substances and also quantifies the PERI posed by the PTE [32,54,55]. The results for the measured selected elements in BAC soil samples are given in Table 3. The mean values of the PTE in the samples were, in decreasing order, $\mathrm{Cd}>\mathrm{As}>\mathrm{Ni}>\mathrm{Cu}>\mathrm{Pb}>\mathrm{Co}>\mathrm{Cr}>\mathrm{Zn}$. Only the values for $\mathrm{Cd}$ were in the range of moderate to considerable ecological risk. Based on these data, five of the sampling locations in the agricultural area pose a high potential ecological risk (potential ecological risk index $>130$ ).

Table 3. Potential ecological risk and potential ecological risk index (PERI) of PTE in the agricultural soils.

\begin{tabular}{cccccccccc}
\hline \multicolumn{1}{c}{ Degree of Ecological Risk of Each Element } & \multicolumn{3}{c}{ Potential Ecological Risk Index } \\
\hline & As & Cd & Co & Cr & Cu & Ni & Pb & Zn \\
\hline Maximum & 13.47 & 101.73 & 8.72 & 6.90 & 9.58 & 20.45 & 9.60 & 1.21 & 156.22 \\
Mean & 10.00 & 41.71 & 5.00 & 3.71 & 5.98 & 9.06 & 5.60 & 1.00 & 82.05 \\
Minimum & 6.73 & 13.96 & 3.14 & 1.64 & 3.63 & 4.22 & 3.52 & 0.70 & 156.22 \\
\hline
\end{tabular}

\subsection{Multivariate Statistical Analysis}

Potential correlations between the studied PTE and the soil physicochemical parameters were identified through Pearson's correlation analysis (Table 4). A significate and positive correlation were found between $\mathrm{Sc}$ and $\mathrm{Al}, \mathrm{Fe}, \mathrm{Cd}, \mathrm{Cr}, \mathrm{Cu}, \mathrm{Mn}, \mathrm{Mo}, \mathrm{Ni}, \mathrm{V}$, and $\mathrm{Zn}$. Except for $\mathrm{As}$ and $\mathrm{Pb}$, all of the PTE concentrations are highly associated with each other, indicating probable similar origins. As indicated by Peris et al. for agricultural soils in Spain [53], Cr and Mn are also highly correlated with Fe, Co, and Ni suggesting an affinity between them $(r>0.55 ; p<0.01)$. Element concentrations were not well correlated with physicochemical properties, suggesting that the effect of the physicochemical properties on the total contents of studied elements is not very important in the study area. Similar results were also indicated by Manta et al. [56] or Acosta et al. [57] for neutral-alkaline soils, like our samples (soil $\mathrm{pH}=7.3-8.45$ ).

The inter-element relationships give information useful for identifying the sources of PTE in environmental matrices [58]. In the present study, the PCA was used to identify different element sources and anthropogenic activities (Table 5).

According to the PCA analyses, three components were described to classify the possible sources of elements. These components explain $77 \%$ of the variance in the data. Component 1 , which explains $42.9 \%$ of the variance, was significantly loaded by $\mathrm{Fe}, \mathrm{Co}, \mathrm{Al}, \mathrm{Cu}, \mathrm{Cr}, \mathrm{Sc}, \mathrm{V}, \mathrm{Mn}$, and $\mathrm{Zn}$. Component 2 explained $19.45 \%$ of the variance and was loaded by $\mathrm{Cd}, \mathrm{Ni}, \mathrm{P}$, and $\mathrm{Pb}$. Finally, component 3 explained $14 \%$ of the variance and was composed of clay, $\mathrm{Pb}$ and As. Also, $\mathrm{Cr}$ received approximately similar loading factors in PC1 and PC2. Hence, it exhibited a quasi-independent behaviour in the agricultural soil samples, indicating that $\mathrm{Cr}$ might have mixed sources. 
Table 4. Pearson's correlation analysis of PTE in agricultural soils.

\begin{tabular}{|c|c|c|c|c|c|c|c|c|c|c|c|c|c|c|c|c|c|c|c|c|}
\hline & Sc & $\mathrm{Cd}$ & $\mathrm{Cr}$ & $\mathrm{Cu}$ & $\mathrm{Fe}$ & $\mathrm{Ni}$ & $\mathrm{Zn}$ & Al & Co & Mn & Mo & $\mathrm{V}$ & $\mathrm{As}_{-}$ & $\mathrm{Pb}$ & CEC & $\mathrm{pH}$ & OC & Sand & Silt & Clay \\
\hline Sc & 1 & & & & & & & & & & & & & & & & & & & \\
\hline $\mathrm{Cd}$ & 0.65 & 1 & & & & & & & & & & & & & & & & & & \\
\hline $\mathrm{Cr}$ & 0.66 & -0.65 & 1 & & & & & & & & & & & & & & & & & \\
\hline $\mathrm{Cu}$ & 0.88 & -0.56 & 0.51 & 1 & & & & & & & & & & & & & & & & \\
\hline $\mathrm{Fe}$ & 0.96 & -0.59 & 0.69 & 0.87 & 1 & & & & & & & & & & & & & & & \\
\hline $\mathrm{Ni}$ & 0.86 & -0.58 & 0.79 & 0.76 & 0.83 & 1 & & & & & & & & & & & & & & \\
\hline $\mathrm{Zn}$ & 0.60 & $\mathrm{NC}$ & $\mathrm{NC}$ & 0.64 & 0.66 & 0.46 & 1 & & & & & & & & & & & & & \\
\hline $\mathrm{Al}$ & 0.87 & NC & $\mathrm{NC}$ & 0.84 & 0.86 & 0.75 & 0.78 & 1 & & & & & & & & & & & & \\
\hline Co & 0.95 & -0.6 & 0.74 & 0.87 & 0.93 & 0.94 & 0.59 & 0.86 & 1 & & & & & & & & & & & \\
\hline $\mathrm{Mn}$ & 0.67 & -0.46 & 0.61 & 0.76 & 0.76 & 0.55 & $\mathrm{NC}$ & 0.51 & 0.62 & 1 & & & & & & & & & & \\
\hline Mo & -0.84 & 0.72 & -0.75 & -0.638 & -0.81 & -0.72 & $\mathrm{NC}$ & -0.63 & 0.76 & -0.52 & 1 & & & & & & & & & \\
\hline $\mathrm{V}$ & 0.95 & -0.68 & 0.73 & 0.82 & 0.96 & 0.77 & 0.519 & 0.76 & 0.88 & 0.67 & -0.88 & 1 & & & & & & & & \\
\hline As & $\mathrm{NC}$ & $\mathrm{NC}$ & $\mathrm{NC}$ & $\mathrm{NC}$ & $\mathrm{NC}$ & $\mathrm{NC}$ & $\mathrm{NC}$ & $\mathrm{NC}$ & $\mathrm{NC}$ & $\mathrm{NC}$ & $\mathrm{NC}$ & $\mathrm{NC}$ & 1 & & & & & & & \\
\hline $\mathrm{Pb}$ & NC & 0.63 & -0.55 & NC & NC & NC & NC & NC & NC & NC & NC & -0.46 & $\mathrm{NC}$ & 1 & & & & & & \\
\hline CEC & 0.51 & -0.61 & 0.46 & 0.49 & NC & 0.48 & NC & NC & 0.52 & NC & NC & 0.50 & $\mathrm{NC}$ & $\mathrm{NC}$ & 1 & & & & & \\
\hline $\mathrm{pH}$ & NC & $\mathrm{NC}$ & 0.52 & $\mathrm{NC}$ & NC & $\mathrm{NC}$ & $\mathrm{NC}$ & $\mathrm{NC}$ & $\mathrm{NC}$ & 0.62 & $\mathrm{NC}$ & 0.51 & $\mathrm{NC}$ & $\mathrm{NC}$ & $\mathrm{NC}$ & 1 & & & & \\
\hline OC & -0.49 & $\mathrm{NC}$ & NC- & -0.58 & -0.48 & NC & $\mathrm{NC}$ & -0.53 & -0.47 & -0.55 & $\mathrm{NC}$ & NC & $\mathrm{NC}$ & NC & $\mathrm{NC}$ & NC & 1 & & & \\
\hline Sand & NC & $\mathrm{NC}$ & NC & $\mathrm{NC}$ & $\mathrm{NC}$ & NC & $\mathrm{NC}$ & -0.58 & NC & NC & NC & NC & NC & NC & $\mathrm{NC}$ & NC & $\mathrm{NC}$ & 1 & & \\
\hline Silt & 0.48 & $\mathrm{NC}$ & $\mathrm{NC}$ & $\mathrm{NC}$ & $\mathrm{NC}$ & $\mathrm{NC}$ & $\mathrm{NC}$ & 0.68 & 0.50 & NC & $\mathrm{NC}$ & NC & $\mathrm{NC}$ & $\mathrm{NC}$ & 0.48 & $\mathrm{NC}$ & $\mathrm{NC}$ & -0.98 & 1 & \\
\hline Clay & -0.61 & $\mathrm{NC}$ & -0.58 & $\mathrm{NC}$ & -0.68 & $\mathrm{NC}$ & $\mathrm{NC}$ & $\mathrm{NC}$ & -0.48 & -0.74 & 0.60 & -0.67 & $\mathrm{NC}$ & 0.517 & $\mathrm{NC}$ & -0.61 & 0.46 & $\mathrm{NC}$ & $\mathrm{NC}$ & 1 \\
\hline
\end{tabular}

NC No correlation; bold letter, stands for highly significant correlations $(p<0.01)$; Italic letter stands for significant correlations $(p<0.05)$. 
In general, it seems that a "geogenic factor" is the most significant source of PTE in the studied soils, as indicated by component 1 and previously indicated by Moghtaderi et al. (2018) for industrial areas [9]. Component 2 could be called as "anthropogenic factor" and was constituted by Cd, Ni, P, and $\mathrm{Pb}$ with a source from anthropogenic origins, such as industrial/transport emissions or agricultural practices (e.g., agricultural machinery, pesticides, and fertilizers) $[13,36,42,48,59]$. The presence of $P$ with these PTEs in this component reinforces the possibility that agricultural malpractice could be the source of these elements, such as phosphate fertilizers and uncontrolled uses of pesticides $[8,48,51,59,60]$. Although Cd levels were lower, uncontrolled use of phosphate fertilizers could be an explanation for this common origin on Component $2[59,61]$, as also observed by Cheraghi et al. [60] for agricultural farmlands in the Hamadan province (Western Iran) or by Micó et al. [59] for agricultural soils in Spain. Interestingly, component 3 was formed by clay and As. This combination could have an "atmospheric origin", as indicated by Li et al. [48] for arid agricultural soils in China, where arsenic is related to fine soil fractions (e.g., clay fraction) with an origin of wind erosion.

Table 5. Principal component analysis for physicochemical properties and PTE in BAC soils.

\begin{tabular}{cccc}
\hline & \multicolumn{3}{c}{ Agricultural Soils } \\
\hline & PC1 & PC2 & PC3 \\
\hline Fe & $\mathbf{0 . 9 6}$ & -0.04 & -0.22 \\
$\mathrm{Al}$ & $\mathbf{0 . 9 4}$ & -0.20 & 0.01 \\
$\mathrm{Cu}$ & $\mathbf{0 . 9 4}$ & 0.10 & 0.24 \\
$\mathrm{~V}$ & $\mathbf{0 . 9 1}$ & -0.17 & 0.02 \\
$\mathrm{Sc}$ & $\mathbf{0 . 9 0}$ & -0.17 & -0.29 \\
$\mathrm{Mo}$ & $\mathbf{0 . 8 9}$ & -0.02 & -0.19 \\
$\mathrm{Zn}$ & -0.78 & 0.11 & 0.31 \\
$\mathrm{Mn}$ & $\mathbf{0 . 7 2}$ & 0.43 & 0.14 \\
$\mathrm{Cr}$ & $\mathbf{0 . 7 0}$ & -0.15 & -0.45 \\
$\mathrm{OC}$ & $\mathbf{0 . 6 4}$ & 0.47 & -0.33 \\
$\mathrm{P}$ & -0.53 & 0.13 & 0.12 \\
$\mathrm{Cd}$ & -0.01 & $\mathbf{0 . 8 9}$ & 0.26 \\
$\mathrm{Ni}$ & -0.29 & $\mathbf{0 . 8 7}$ & 0.25 \\
$\mathrm{~Pb}$ & 0.02 & $\mathbf{0 . 6 5}$ & -0.02 \\
CEC & -0.08 & $\mathbf{0 . 7 1}$ & 0.49 \\
Clay & 0.49 & -0.51 & 0.16 \\
As & -0.53 & -0.05 & $\mathbf{0 . 7 8}$ \\
pH & 0.19 & 0.23 & $\mathbf{0 . 7 6}$ \\
\% of Variance & 0.31 & -0.34 & -0.66 \\
\hline Cumulative \% & 42.92 & 19.45 & 14.00 \\
Bartlett's sphericity tests $(p=0) ;$ Kaiser-Meyer-Olkin (KMO = & 42.92 & 62.37 & 76.37 \\
\hline & & &
\end{tabular}

\section{Conclusions}

The concentrations of 11 PTEs and their pollution level in agricultural soils from BAC were quantified in this study. In general, the contamination level of our samples was low, and seems to be related to the agricultural activities, with a low influence from industrial or urban sources. According to the different analysis, there are mixed natural/geogenic and anthropogenic sources in the studied soils, mainly to the malpractices of application of phosphate fertilizers. In general, chromium and nickel are priority PTEs for control in the studied soils. Furthermore, the potential impact of these PTEs on plant uptake or water resources should be considered for further works. Finally, this work provides a basis for the implementation of public policies to reduce the input of PTE in agricultural soils, and therefore, to reduce their long term accumulation, both in soils and in their possible uptake by biota.

Supplementary Materials: The following are available online at http://www.mdpi.com/2073-4395/10/4/564/s1, Table S1: Indices of pollution assessment for studied potentially toxic elements. 
Author Contributions: Conceptualization, T.M. and A.S.; Methodology, T.M. and A.S.; Validation and Formal Analysis, T.M., A.S., and A.R.-S.; Investigation, T.M. and A.S.; Resources, T.M. and A.S.; Writing-Original Draft Preparation, T.M. and A.S.; Writing-Review \& Editing, T.M., A.S., and A.R.-S.; Supervision, A.S.; Funding Acquisition, A.S. All authors have read and agreed to the published version of the manuscript.

Funding: This research received no external funding. The APC was funded by ARS.

Acknowledgments: We thank the research committee of Science and Research Branch, Islamic Azad University, Tehran, Iran and the Environment Protection organization of Hormozgan province for financial support and providing the required equipment. This research was also supported by the Strategic Funding UID/Multi/04423/2019 (CIIMAR) through national funds provided by FCT (Foundation for Science and Technology) and the European Regional Development Fund (ERDF), in the framework of the PT2020 Partnership Agreement. A.R.-S would like to express their thanks to the FCT (Foundation for Science and Technology) for their individual research contract (CEECIND/03794/2017).

Conflicts of Interest: The authors declare no conflict of interest. The funders had no role in the design of the study; in the collection, analyses, or interpretation of data; in the writing of the manuscript, or in the decision to publish the results.

\section{References}

1. Huang, S.S.; Liao, Q.L.; Hua, M.; Wu, X.M.; Bi, K.S.; Yan, C.Y.; Zhang, X.Y. Survey of heavy metal pollution and assessment of agricultural soil in Yangzhong district, Jiangsu Province, China. Chemosphere 2017, 67, 2148-2155. [CrossRef]

2. Huo, X.N.; Li, H.; Sun, D.F.; Zhou, L.D.; Li, B.G. Multi-scale spatial structure of heavy metals in agricultural soils in Beijing. Environ. Monit. Assess. 2010, 164, 605-616.

3. Rodríguez-Martín, J.A.; Ramos-Miras, J.J.; Boluda, R.; Gil, C. Spatial relations of heavy metals in arable and green house soils of a Mediterranean environment region (Spain). Geoderma 2013, 200-201, 180-188. [CrossRef]

4. Benhaddya, M.L.; Hadjel, M. Spatial distribution and contamination assessment of heavy metals in surface soils of HassiMessaoud, Algeria. Environ. Earth Sci. 2014, 71, 1473-1486. [CrossRef]

5. Ullah, Z.; Naz, A.; Saddique, U.; Khan, A.; Shah, W.; Muhammad, S. Potentially toxic elements concentrations and human health risk assessment of food crops in Bajaur Agency, Pakistan. Environ. Earth Sci. 2017, 76, 482. [CrossRef]

6. Muhammad, S.; Ullah, R.; Jadoon, I.A.K. Heavy metals contamination in soil and food and their evaluation for risk assessment in the Zhob and Loralai valleys, Baluchistan province, Pakistan. Microchem. J. 2019, 149, 103971. [CrossRef]

7. Tóth, G.; Hermann, T.; Da Silva, M.R.; Montanarella, L. Heavy metals in agricultural soils of the European Union with implications for food safety. Environ. Int. 2016, 88, 299-309. [CrossRef]

8. Khalifa, M.; Gad, A. Assessment of Heavy Metals Contamination in Agricultural Soil of Southwestern Nile Delta, Egypt. Soil Sediment Contam. 2018, 27, 619-642. [CrossRef]

9. Moghtaderi, T.; Mahmoudi, S.; Shakeri, A.; Masihabadi, M.H. Heavy metals contamination and human health risk assessment in soils of an industrial area, Bandar Abbas-South Central Iran. Hum. Ecol. Risk Assess. 2018, 24, 1058-1073. [CrossRef]

10. Moghtaderi, T.; Mahmodi, S.; Shakeri, A.; Masihabadi, M.H. Contamination evaluation, health and ecological risk index assessment of potential toxic elements in the surface soils (case study: Central Part of Bandar Abbas County). J. Soil Water Conserv. 2019, 8, 51-65.

11. Moghtaderi, T.; Aminiyan, M.M.; Alamdar, R.; Moghtaderi, M. Index-based evaluation of pollution characteristics and health risk of potentially toxic metals in schools dust of Shiraz megacity, SW Iran. Hum. Ecol. Risk Assess. 2019, 25, 410-437. [CrossRef]

12. Doabi, S.A.; Karami, M.; Afyuni, M.; Yeganeh, M. Pollution and health risk assessment of heavy metals in agricultural soil, atmospheric dust and major food crops in Kermanshah province, Iran. Ecotoxicol. Environ. Saf. 2018, 163, 153-164. [CrossRef] [PubMed]

13. Doabi, S.; Karami, M.; Afyuni, M. Heavy metal pollution assessment in agricultural soils of Kermanshah province, Iran. Environ. Earth Sci. 2019, 78, 70. [CrossRef] 
14. Keshavarzi, B.; Abbasi, S.; Moore, F.; Mehravar, S.; Sorooshian, A.; Soltani, N.; Najmeddin, A. Contamination Level, Source Identification and Risk Assessment of Potentially Toxic Elements (PTEs) and Polycyclic Aromatic Hydrocarbons (PAHs) in Street Dust of an Important Commercial Center in Iran. Environ. Manag. 2018, 62, 803-818. [CrossRef] [PubMed]

15. Bakhtiari, B.; Kermanib, M.N.; Bordbar, M.H. Rain Gauge Station Network Design for Hormozgan Province in Iran. Desert 2013, 18, 45-52.

16. Dadras, M.; Shafri, H.Z.; Ahmad, N.; Pradhan, B.; Safarpour, S. Spatio-temporal analysis of urban growth from remote sensing data in Bandar Abbas city, Iran. Egypt. J. Remote Sens. Space Sci. 2015, 18, 35-52. [CrossRef]

17. Keshavarzi, B.; Tazarvi, Z.; Rajabzadeh, M.A.; Najmeddin, A. Chemical speciation, human health risk assessment and pollution level of selected heavy metals in urban street dust of Shiraz, Iran. Atmos. Environ. 2015, 119, 1-10. [CrossRef]

18. Zheng, N.; Liu, J.; Wang, Q.; Liang, Z. Health risk assessment of heavy metal exposure to street dust in the zinc smelting district, Northeast of China. Sci. Total Environ. 2010, 408, 726-733. [CrossRef]

19. Gee, G.W.; Bauder, J.W. Particle-size Analysis. In Methods of Soil Analysis; Klute, A., Ed.; SSSA: Madison, WI, USA, 1986; pp. 383-411.

20. Gaudette, H.E.; Flight, W.R.; Toner, L.; Folger, D.W. An inexpensive titration method for the determination of organic carbon in recent sediments. J. Sediment. Petrol. 1974, 44, 249-253.

21. Hendershot, W.H.; Duquette, M. A simple barium chloride method for determining cation exchange capacity and exchangeable cations. Soil Sci. Soc. Am. J. 1986, 50, 605-608. [CrossRef]

22. Krzysztof, L.; Wiechula, D.; Korns, I. Metal contamination of farming soils affected by industry. Environ. Int. 2004, 30, 159-165.

23. Li, P.; Lin, C.; Cheng, H.; Duan, X.; Lei, K. Contamination and health risks of soil heavy metals around a lead/zinc smelter in southwestern China. Ecotoxicol. Environ. Saf. 2015, 113, 391-399. [CrossRef] [PubMed]

24. Xiang, J.; Wang, J.; Chen, L.; Ling, Z.; Han, J.; Li, Q.; Wang, Q. Distribution, Source Identification, and Assessment of Potentially Toxic Elements in the Sediment Core from the Estuarine Region of the Golmud River to the Qarhan Salt Lake, Qinghai, China. Minerals 2019, 9, 506. [CrossRef]

25. Abrahim, G.M.S.; Parker, R.J. Assessment of heavy metal enrichment factors and the degree of contamination in marine sediments from Tamaki Estuary, Auckland, New Zealand. Environ. Monit. Assess. 2008, 136, 227-238. [CrossRef]

26. Hakanson, L. An ecological risk index for aquatic pollution control. A sedimentological approach. Water Res. 1980, 14, 975-1001. [CrossRef]

27. Abrahim, G.M.S. Holocene Sediments of Tamaki Estuary. Characterization and Impact of Recent Human Activity on an Urban Estuary in Auckland, New Zealand. Ph.D. Thesis, University of Auckland, Auckland, New Zealand, 2005; p. 361. Available online: http://hdl.handle.net/2292/1419 (accessed on 2 April 2020).

28. Shakeri, A.; Moore, F.; Modabberi, S. Heavy metal contamination and distribution in the Shiraz Industrial Complex Zone soil, South Shiraz, Iran. World Appl. Sci. J. 2009, 6, 413-425.

29. Tang, R.; Ma, K.; Zhang, Y.; Mao, Q. The spatial characteristics and pollution levels of metals in urban street dust of Beijing, China. Appl. Geochem. 2013, 35, 88-98. [CrossRef]

30. Paramasivam, K.; Ramasamy, V.; Suresh, G. Impact of sediment characteristics on the heavy metal concentration and their ecological risk level of surface sediments of Vaigai river, Tamilnadu, India. Spectrochim. Acta A Mol. Biomol. Spectrosc. 2015, 137, 397-407. [CrossRef]

31. Shakeri, A.; Shakeri, R.; Mehrabi, B. Contamination, toxicity and risk assessment of heavy metals and metalloids in sediments of Shahid Rajaie Dam, Sefidrood and Shirinrood Rivers, Iran. Environ. Earth Sci. 2016, 75, 679. [CrossRef]

32. Luo, W.; Lu, Y.; Giesy, J.P.; Wang, T.; Shi, Y.; Wang, G.; Xing, Y. Effects of land use on concentrations of metals in surface soils and ecological risk around Guanting Reservoir, China. Environ. Geochem. Health 2007, 29, 459-471. [CrossRef]

33. Islam, S.; Ahmed, K.; Mamun, H.; Masunaga, S. Potential ecological risk of hazardous elements in different land-use urban soils of Bangladesh. Sci. Total Environ. 2015, 512-513, 94-102. [CrossRef] [PubMed]

34. Zhao, N.; Lu, X.W.; Chao, S.G. Level and contamination assessment of environmentally sensitive elements in smaller than $100 \mu \mathrm{m}$ street dust particles from Xining, China. Int. J. Environ. Res. Public Health 2014, 11, 2536-2549. [CrossRef] [PubMed] 
35. Bourennane, H.; Douay, F.; Sterckeman, T.; Villanneau, E.; Ciesielski, H.; King, D.; Baize, D. Mapping of anthropogenic trace elements inputs in agricultural topsoil from Northern France using enrichment factors. Geoderma 2010, 157, 165-174. [CrossRef]

36. Rodríguez-Seijo, A.; Andrade, M.L.; Vega, F.A. Origin and spatial distribution of metals in urban soils. J. Soils Sedim. 2017, 17, 1514. [CrossRef]

37. Hernandez, L.; Probst, A.; Probst, J.L.; Ulrich, E. Heavy metal distribution in some French forest soil, evidence for atmospheric contamination. Sci. Total Environ. 2003, 312, 195-219. [CrossRef]

38. Mirzaei Aminiyan, M.; Baalousha, M.; Mousavi, R.; Mirzaei Aminiyan, F.; Hosseini, H.; Heydariyan, A. The ecological risk, source identification, and pollution assessment of heavy metals in road dust: A case study in Rafsanjan, SE Iran. Environ. Sci. Pollut. Res. 2018, 25, 13382-13395. [CrossRef]

39. CCME. Canadian Soil Quality Guidelines for the Protection of Environment and Human Health; Canadian Council of Ministers of the Environment: Winnipeg, MB, Canada, 2018.

40. Esmaeli, A.; Moore, F.; Keshavarzi, B.; Jaafarzadeh, N.; Kermani, M. A geochemical survey of heavy metals in agricultural and background soils of the Isfahan industrial zone, Iran. Catena 2014, 121, 88-89. [CrossRef]

41. Pourang, N.; Noori, A.S. Heavy Metals Contamination in Soil, Surface Water and Groundwater of an Agricultural Area Adjacent to Tehran oil Refinery, Iran. Int. J. Environ. Res. 2014, 8, 871-886.

42. Kabata-Pendias, A. Trace Elements in Soils and Plants, 4th ed.; CRC Press: Boca Raton, FL, USA, 2010; pp. 41-42.

43. Mohammadpour, G.A.; Karbassi, A.R.; Baghvand, A. Origin and spatial distribution of metals in agricultural soils. Global J. Environ. Sci. Manag. 2016, 2, 145-156.

44. Keshavarzi, B.; Moore, F.; Ansari, M.; Rastegari Mehr, M.; Kaabi, H.; Kermani, M. Macronutrients and trace metals in soil and food crops of Isfahan Province, Iran. Environ. Monit. Assess. 2015, 187, 4113. [CrossRef]

45. Rahmanipour, F.; Marziaoli, R.; Bahrami, H.A.; Fereidouni, Z.; Rahimi Bandarabadi, S. Assessment of soil quality indices in agricultural lands of Qazvin Province, Iran. Ecol. Indic. 2014, 40, 19-26. [CrossRef]

46. Mirzaei, R.; Teymourzade, S.; Sakizadeh, M.; Ghorbani, H. Comparative study of heavy metals concentration in topsoil of urban green space and agricultural land uses. Environ. Monit. Assess. 2015, 187, 741. [CrossRef] [PubMed]

47. Ahmadi, M.; Jorfi, S.; Azarmansuri, A.; Jaafarzadeha, N.; Hosein Mahvi, A.; Darvishi Cheshmeh Soltani, R.; Akbari, H.; Akhbarizadeh, R. Zoning of heavy metal concentrations including $\mathrm{Cd}, \mathrm{Pb}$ and As in agricultural soils of Aghili plain, Khuzestan province, Iran. Data Brief 2017, 14, 20-27. [CrossRef] [PubMed]

48. Li, Y.; Gou, X.; Wang, G.; Zhang, Q.; Su, Q.; Xiao, G. Heavy metal contamination and source in arid agricultural soil in central Gansu Province, China. J. Environ. Sci. 2008, 20, 607-612. [CrossRef]

49. Kouchou, A.; El Ghachtouli, N.; Duplay, J.; Ghazi, M.; Elsass, F.; Thoisy, J.C.; Bellarbi, M.; Ijjaali, M.; Rais, N. Evaluation of the environmental and human health risk related to metallic contamination in agricultural soils in the Mediterranean semi-arid area (Saiss plain, Morocco). Environ. Earth Sci. 2020, 79, 131. [CrossRef]

50. Carkovic, A.B.; Calcagni, M.S.; Vega, A.S.; Coquery, M.; Moya, P.M.; Bonilla, C.A.; Pastén, P.A. Active and legacy mining in an arid urban environment: Challenges and perspectives for Copiapó, Northern Chile. Environ. Geochem. Health 2016, 38, 1001-1014. [CrossRef]

51. Yang, P.; Mao, R.; Shao, H.; Gao, Y. An investigation on the distribution of eight hazardous heavy metals in the suburban farmland of China. J. Hazard Mater. 2009, 167, 1246-1251. [CrossRef] [PubMed]

52. Micó, C.; Peris, M.; Sánchez, J.; Recatalá, L. Heavy metal content of agricultural soils in a Mediterranean semiarid area: The Segura River Valley (Alicante, Spain). Span. J. Agric. Res. 2006, 4, 363-372. [CrossRef]

53. Peris, M.; Recatalá, L.; Micó, C.; Sánchez, R.; Sánchez, J. Increasing the Knowledge of Heavy Metal Contents and Sources in Agricultural Soils of the European Mediterranean Region. Water Air Soil Pollut. 2008, 192, 25-37. [CrossRef]

54. Maanan, M.; Saddik, M.; Maanan, M.; Chaibi, M.; Assobhei, O.; Zourarah, B. Environmental and ecological risk assessment of heavy metals in sediments of Nador-lagoon, Morocco. Ecol. Indic. 2014, 48, 616-626. [CrossRef]

55. Qing, X.; Yutong, Z.; Shenggao, L. Assessment of heavy metal pollution and human health risk in urban soils of steel industrial city (Anshan), Liaoning, Northeast Chin. Ecotoxicol. Environ. Saf. 2015, 120, 377-385. [CrossRef] [PubMed]

56. Manta, D.D.; Angelone, M.; Bellanca, A.; Neri, R.; Sprovieri, M. Heavy metals in urban soils: A case study from the city of Palermo (Sicily), Italy. Sci. Total Environ. 2002, 300, 229-243. [CrossRef] 
57. Acosta, J.A.; Faz, A.; Martinez-Martinez, S. Identification of heavy metal sources by multivariable analysis in a typical Mediterranean city (SE Spain). Environ. Monit. Assess. 2010, 169, 519-530. [CrossRef] [PubMed]

58. Lu, X.; Wang, L.; Li, L.-.Y.; Lei, K.; Huang, L.; Kang, D. Multivariate statistical analysis of heavy metals in street dust of Baoji, NW China. J. Harzard. Mat. 2010, 173, 744-749. [CrossRef] [PubMed]

59. Micó, C.; Recatalá, L.; Peris, M.; Sánchez, J. Assessing heavy metal sources in agricultural soils of an European Mediterranean area by multivariate analysis. Chemosphere 2006, 65, 863-872. [CrossRef]

60. Cheraghi, M.; Lorestani, B.; Merrikhpour, H. Investigation of the Effects of Phosphate Fertilizer Application on the Heavy Metal Content in Agricultural Soils with Different Cultivation Patterns. Biol. Trace Elem. Res. 2012, 145, 87. [CrossRef]

61. Lugon-Moulin, N.; Ryan, L.; Donini, P.; Rossi, L. Cadmium content of phosphate fertilizers used for tobacco. Agron Sustain. Dev. 2006, 26, 151-155. [CrossRef]

(C) 2020 by the authors. Licensee MDPI, Basel, Switzerland. This article is an open access article distributed under the terms and conditions of the Creative Commons Attribution (CC BY) license (http://creativecommons.org/licenses/by/4.0/). 